\title{
OUTBREAK OF LEAD POISONING IN HIGH VOLTAGE TOWER CONSERVATORS
}

\section{PATRYCJA KRAWCZYK, JOLANTA WALUSIAK, BOGDAN SZULC, ANNA KRAKOWIAK, MARTA WISZNIEWSKA, TOMASZ WITTCZAK, and CEZARY PAŁCZYŃSKI}

Department of Occupational Diseases

Nofer Institute of Occupational Medicine

Lódź, Poland

\begin{abstract}
Objectives: A changing character of lead exposure has been observed over many years. However, construction workers involved in the renovation of painted steel structures are still severely exposed to lead and its compounds. In 2004, we observed an outbreak of lead poisoning in high voltage tower conservators working abroad. Materials and Methods: As many as 27 male workers with suspected lead poisoning were hospitalized in the Department of Occupational Disease, Nofer Institute of Occupational Medicine, Łódź, Poland. They were involved in removing an old lead-containing paint from high voltage towers. Results: On admission to the department, $70 \%$ of treated workers showed laboratory signs of anemia in their blood count. After treatment the signs persisted in $25 \%$ of patients. Also alkaline dotting in erythrocytes was present in 13 subjects. Sub-acute lead poisoning manifested by abdominal cramps with coexisting anemia and increased lead absorption symptoms was most frequently diagnosed. Conclusions: The high lead exposure of the examined high voltage tower cleaners was due to specific working conditions. In such cases overprotection of the environment may lead to severe health effects in humans.
\end{abstract}

Key words:

Lead poisoning, Occupational exposure

\section{INTRODUCTION}

Lead is one of the best known occupational hazards. A substantial number of industrial workers have contact with lead and its compounds. There are several operations, in which the risk of poisoning may occur, e.g., welding and cutting of lead constructions, shipbreaking, lead smelting, spray painting, mixing of crystal glass mass, sanding or scraping of lead paints. In the majority of industrialized countries, extremely poor hygiene conditions in industry are now rarely encountered in industrial plants, however, in some cases working conditions are far from being acceptable [1-3].

Because of severe acute and/or chronic health effects, lead from gasoline, paints and ceramic products, caulking, and pipe solder has been dramatically reduced in recent years, nevertheless there are still some sources of lead like old constructions, walls and windows paintings [4]. Inhalation, ingestion from food and water contamination are often main routs of lead absorption [5]. Lead may induce a wide range of health effects, but their symptoms are not specific. They are most frequently manifested by abdominal cramps, vomiting, tiredness, attention deficit disorder, constipation, anemia, nerve damage, convulsions, anorexia, learning disabilities, and brain damage. Such symptoms occur in many disorders and they frequently can be falsely diagnosed [6]. The influence of lead on the human body is multidirectional, but the hematopoietic system is a primary target for its toxicity in adults. Lead exerts toxic effects on the red blood cell membrane

Received: August 14, 2006. Accepted: September 18, 2006.

Address reprint requests to P. Krawczyk, MD, PhD, Department of Occupational Diseases, Nofer Institute of Occupational Medicine, św. Teresy 8, $91-348$ Łódź, Poland (e-mail: patrycja72@tlen.pl). 
and hinders the heme synthesis leading to anemia. The impaired heme synthesis is responsible for higher blood concentration of $\sigma$-aminolevulinic acid (ALA) and erythrocyte zinc protoporphyrin (EZP). Lead also significantly affects the central and peripheral nervous system and immune response, which induces oxidative stress resulting in DNA damage. High and prolonged exposure to lead may also cause nephropathy characterized by a progressive impairment of renal function [7-10].

In workers with saturnismus incipiens, distinguished by the increased blood lead (B-Pb) level of over $500 \mu \mathrm{g} / \mathrm{l}$, sings of anemia and the presence of general symptoms after exposure cessation, the chelaton therapy should be applied depending on blood and urine lead (U-Pb) concentrations. $\mathrm{U}-\mathrm{Pb}$ concentration is crucial for the chelaton test. Chelaton releases lead from bone deposits. The test is positive when excessive urine lead $(>1000 \mu \mathrm{g} / \mathrm{l})$ elimination is found $[11,12]$.

A changing character of lead exposure has recently been observed. Over the last years, decreased B-Pb levels have been found in workers mostly due to advances in occupational engineering and monitoring. For example, in Poland like in other EU countries, acute lead poisoning has not been recorded for many years except for a few single cases noted annually usually in workers employed in small factories producing car batteries or scrap metal processing. However, construction workers involved in the renovation of painted steel structures are still heavily exposed [13].

\section{MATERIALS AND METHODS}

In 2004, twenty seven male workers with suspected lead poisoning were hospitalized in the Department of Occupational Disease, Nofer Institute of Occupational Medicine, Łódź, Poland. They were seasonal workers removing old paint while restoring high voltage towers in Germany. The mean age in the group was 34 years. The majority $(48 \%)$ of workers performed this kind of job for the first time (Table 1).

To protect the environment from lead contamination all towers were covered with special material and workers found themselves inside a big tunnel (Fig. 1).
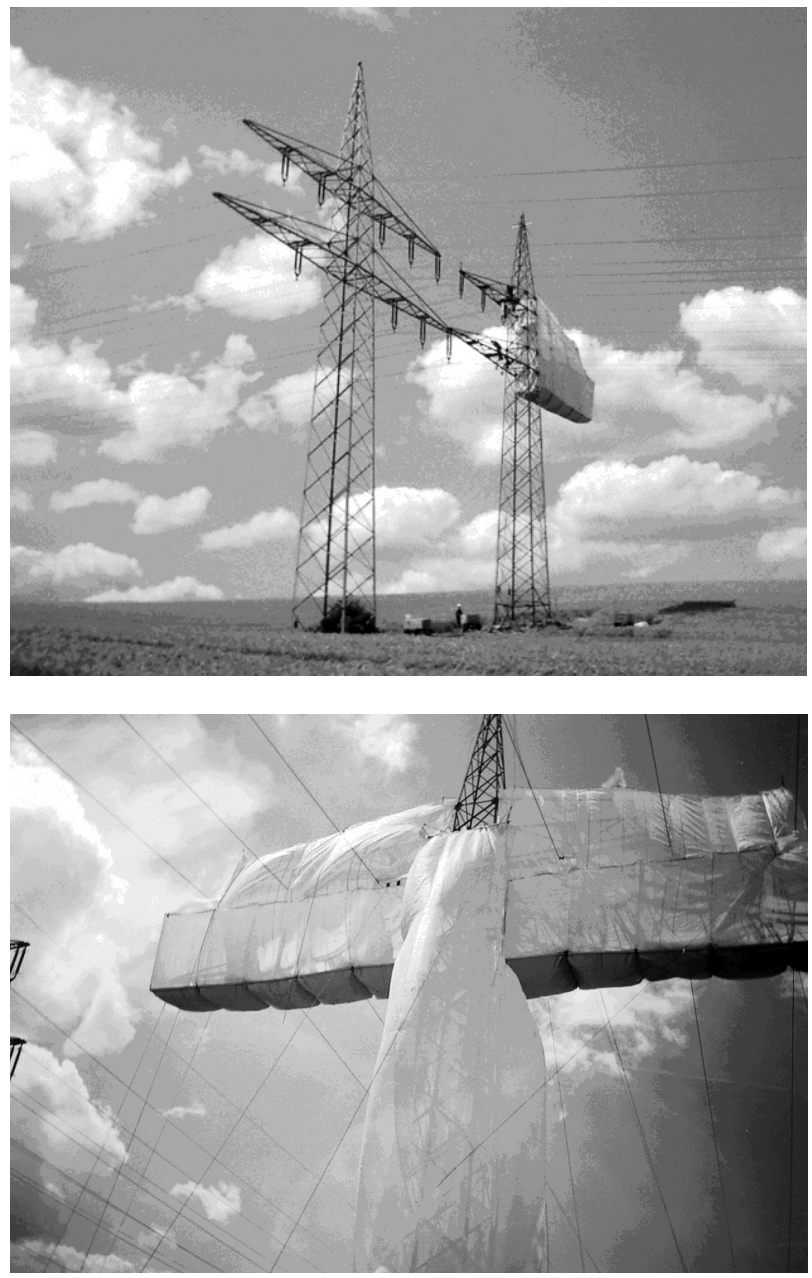

Fig. 1. High voltage towers prepared for cleaning.

To remove paint pneumatic hammers, steel brushes, spatulas and screwdrivers were used. Conservators worked an eight-hour shift in groups of 4-8 workers. They were supplied with personal protection, including overalls, antidust masks, helmets and gloves. They were eating, drinking and smoking during breaks outside the tunnel. During their stay in Germany or right after coming back home, after 5-45 weeks of work, all of them suffered from health problems, such as abdominal cramps (lead colic), constipations, weakness, nausea, vomiting, lack of appetite, limbs pain, headache, and vertigo. Abdominal cramps and weakness were the most common symptoms which suggested lead poisoning (Tables 1 and 2). Moreover, symptoms suggesting peripheral neuropathy like pain (37\%), pins and needles or numbness $(26 \%)$ of distal parts of the limbs were reported by the workers. The time-lag between 
Table 1. Characteristics of the study population

\begin{tabular}{lc}
\hline \multicolumn{1}{c}{ Characteristics } & Mean \pm SD \\
\hline Age (years) & $34.11 \pm 8.68$ (range, 22-51 years) \\
Duration of exposure prior & $17.15 \pm 9.13$ (range, 5-56) \\
to hospitalization (weeks) & \\
Duration of exposure proceeding & $11.26 \pm 9.54$ (range, 5-45) \\
first symptoms (weeks) & \\
Time-lag between first symptoms & $5.74 \pm 5.24$ (range, $0-18)$ \\
and hospitalization (weeks) & \\
Years of employment & $2.70 \pm 2.35$ (range 1-10 years) \\
as a paint conservator & Number (\%) \\
\hline \multicolumn{1}{c}{ Working as a paint conservator } & $(\mathrm{n}=27)$ \\
\hline First time & $13(48.1)$ \\
Second time & $4(14.8)$ \\
Third time & $3(11.1)$ \\
Fourth time & $1(3.7)$ \\
Fifth time & $1(3.7)$ \\
Sixth time & $4(14.8)$ \\
Tenth time & $1(3.7)$ \\
Seasonal work & $26(96.3)$ \\
\hline
\end{tabular}

SD - standard deviation.

Table 2. Frequency of the symptoms suggesting lead poisoning

\begin{tabular}{lc}
\hline \multicolumn{1}{c}{ Sympotms } & $\begin{array}{c}\text { Number }(\%) \\
(\mathrm{n}=27)\end{array}$ \\
\hline Abdominal cramps & $19(70.4)$ \\
Constipations & $11(40.7)$ \\
Weakness, tiredness & $18(66.7)$ \\
Needles and pins of the limbs & $8(29.6)$ \\
Nausea & $6(22.2)$ \\
Vomiting & $9(33.3)$ \\
Lost of appetite & $11(40.7)$ \\
Diarrhea & $8(29.6)$ \\
Pain of the limbs & $10(37)$ \\
Headache and vertigos & $7(25.9)$ \\
Numbness of the limbs & $7(25.9)$ \\
\hline
\end{tabular}

the occurrence of first symptoms and hospitalization was almost 6 weeks on average (Table 1).

\section{RESULTS}

During hospitalization, all patients underwent standard medical and laboratory tests, neurological examination, including peripheral nerve conduction assessment as well as determination of $\mathrm{B}-\mathrm{Pb}$ level and EZP.
Table 3. Erythrocyte zinc protoporphyrin (EZP), blood lead (B-Pb) and urine lead $(\mathrm{U}-\mathrm{Pb})$ levels in high voltage tower conservators on admission to the clinic

\begin{tabular}{lcc}
\hline Levels & $\begin{array}{c}\text { Mean } \pm \mathrm{SD} \\
(\mu \mathrm{g} / \mathrm{l})\end{array}$ & $\begin{array}{c}\text { Range } \\
(\mu \mathrm{g} / \mathrm{l})\end{array}$ \\
\hline $\mathrm{B}-\mathrm{Pb}$ & $707.73 \pm 284.98$ & $216-1500$ \\
$\mathrm{EZP}$ & $198.28 \pm 119.83$ & $12-409$ \\
$\mathrm{U}-\mathrm{Pb}$ & $103.05 \pm 76.46$ & $14-266$ \\
\hline
\end{tabular}

SD - standard deviation.

Duration of exposure ranged from 5 to 56 weeks, so all the patients were given at least one dose of chelating agent - calcium disodium versenate (calcium EDTA) to eliminate lead from the blood and/or to release bone deposits. According to Polish informative notices for occupational physicians, if a single measurement of $\mathrm{B}-\mathrm{Pb}$ level shows the value over $600 \mu \mathrm{g} / \mathrm{l}$ (for males) the worker should be temporary removed from his work environment [12]. When B-Pb level reaches $400 \mu \mathrm{g} / \mathrm{l}$, special attention should be paid and tests frequently performed in an exposed worker. In the patients treated in our department these values were even higher - mean B-Pb level was over $700 \mu \mathrm{g} / \mathrm{l}$ and the maximum level reached even $1500 \mu \mathrm{g} / \mathrm{l}$. EZP levels were below the threshold level $(700 \mu \mathrm{g} / 1)$. The highest EZP level in the high voltage tower conservator was $409 \mu \mathrm{g} / \mathrm{l}$ (Table 3).

The level of lead was measured in 24-h urine samples after each administration of disodium versenate. Before the treatment, U-Pb level was not high and in only two patients chelaton test was negative. The treatment was stopped when U-Pb level was lower than $400 \mu \mathrm{g} / \mathrm{l}$.

On admission to the department, $70 \%$ of workers showed sings of anemia in their blood count. After treatment the signs persisted in $25 \%$ of patients. Alkaline dotting in erythrocytes, another feature of lead poisoning, was also present in 13 subjects, which reflected toxic effects of lead (Table 4). Renal abnormalities were not found.

According to occupational history, symptoms and all diagnostic tests, of the 27 patients, in only 2 persons lead poisoning was excluded. In 12 patients sub-acute lead poisoning manifested by abdominal cramps with coexisting anemia was diagnosed. The nerve conduction test confirmed peripheral neuropathy in one worker (Table 5). 
Table 4. The results of blood morphology analysis in 27 high voltage tower conservators

\begin{tabular}{lc}
\hline \multicolumn{1}{c}{ Outcome before and after the treatment } & $\begin{array}{c}\text { Number }(\%) \\
(\mathrm{n}=27)\end{array}$ \\
\hline $\begin{array}{l}\text { Anemia (hemoglobin concentration below } 13.0 \mathrm{~g} / \mathrm{dl}) \\
\text { before treatment }\end{array}$ & $19(70.4)$ \\
$\begin{array}{l}\text { Presence of erythrocytes alkaline dotting before } \\
\text { treatment }\end{array}$ & $13(48.1)$ \\
$\begin{array}{l}\text { Anemia (hemoglobin concentration below } 13.0 \mathrm{~g} / \mathrm{dl}) \\
\text { after treatment }\end{array}$ & $7(25.1)$ \\
$\begin{array}{l}\text { Presence of erythrocytes alkaline dotting after } \\
\text { treatment }\end{array}$ & $2(7.4)$ \\
\hline
\end{tabular}

Table 5. Medical diagnosis in the study group

\begin{tabular}{lc}
\hline \multicolumn{1}{c}{ Diagnosis } & $\begin{array}{c}\text { Number (\%) } \\
(\mathrm{n}=27)\end{array}$ \\
\hline $\begin{array}{l}\text { Sub-acute lead poisoning manifested } \\
\text { by abdominal cramps and anemia }\end{array}$ & $12(44.4)$ \\
$\begin{array}{l}\text { Sub-acute lead poisoning manifested by anemia } \\
\text { Sub-acute lead poisoning manifested } \\
\text { by abdominal cramps }\end{array}$ & $2(7.4)$ \\
$\begin{array}{l}\text { Increased lead absorption symptoms } \\
\text { Sub-acute lead poisoning manifested } \\
\text { by polineuropathy }\end{array}$ & $1(3.7)$ \\
Lead poisoning excluded & $9(33.3)$ \\
\hline
\end{tabular}

\section{CONCLUSIONS}

The workers under study were highly exposed to lead due to specific working conditions. The high voltage tower restoring was performed inside a special cover protecting the environment, but leading to the high lead concentration in the working area. Personal protecting equipment in such working microclimate was not adequate to fully protect from dust inhalation. Although there was no data on the on-site lead concentrations they must have been significant according to medical and biochemical findings in the group of conservators. It seems that another type of environment protection - not so tight - could be safer for the workers. This case shows that overprotection of the environment may lead to severe health effects in humans.

\section{REFERENCES}

1. Nriago JO. Lead and Lead Poisoning in Antiquity. New York: Wiley Interscience; 1983.

2. Grilfillan SC. Lead poisoning and the fall of Rome. J Occ Med 1965;7:53-60.

3. Hernberg S. Lead poisoning in a historical perspective. Am J Ind Med 2000;38:244-54.

4. Silbergeld EK. The international dimensions of lead exposure. Int J Occup Environ Health 1995;1:336-48.

5. Rabinovitz M, Wetherill GW, Kopple JD. Magnitude of lead intake from respiration by normal man. J Lab Clin Med 1977;90:238-48.

6. McEachern JS. Some pitfalls in the diagnosis of conditions giving rise to chronic abdominal discomfort. Can Med Assoc J 1934;30(1):8-13.

7. Baker EL, Landrigan PJ, Barbour AG, Cox DH, Folland DS, Ligo RN, et al. Occupational lead poisoning in the United States: Clinical and biochemical findings related to blood lead levels. Br J Ind Med 1979;36:314-22.

8. Lilis R, Fishbain A, Eisinger J, Blumberg WE, Diamond S, Anderson HA, et al. Prevalence of lead disease among secondary lead smelter workers and biological indicators of lead exposure. Environ Res 1977;14:255-85.

9. Bellinger D, Leviton A, Allerd E, Rabinovitz M. Pre- and post-natal lead exposure and behavior problems in school-aged children. Environ Res 1994;66:12-30.

10. Brune D, Nordberg GF, Wester PO. Distribution of 23 elements in the kidney, liver, and lung of workers from a smelter and refinery in North Sweden exposed to a number of elements and of a control group. Sci Tot Environ 1980;16:13-35.

11. Langauer-Lewowicka H, Zając-Nędza M. Lead In: Marek K, editor. Occupational Diseases. Warsaw: Medical Publishers PZWL; 2001. p. 176-83 [in Polish].

12. Jakubowski M, Marek K, Piotrowski JK, Iżycki J. Indications for the Diagnosis and Prevention of Lead Poisoning. Łódź: Nofer Institute of Occupational Medicine; 1997 [in Polish].

13. Marino PE, Franzblau A, Lillis R, Landrigan PJ. Acute lead poisoning in construction workers - The failure of current protective standards. Arch Environ Health 1989;44:140-5. 